\title{
KONSEP UJI VALIDITAS DAN RELIABILITAS DENGAN MENGGUNAKAN SPSS
}

\author{
Nilda Miftahul Janna, (18210047) ${ }^{1}$ \\ Dosen Pembimbing : Herianto, M.PD ${ }^{2}$ \\ ${ }^{1}$ Sekolah Tinggi Agama Islam (STAI) Darul Dakwah Wal-Irsyad (DDI) Kota Makassar, Indonesia \\ Email: nildamiftahuljanna@gmail.com \\ ${ }^{2}$ Sekolah Tinggi Agama Islam (STAI) Darul Dakwah Wal-Irsyad (DDI) Kota Makassar, Indonesia \\ Email: antoherianto47@@gmail.com
}

\begin{abstract}
ABSTRAK
SPSS merupakan salah satu program pengolahan data statistik yang populer di kalangan peneliti, dan sangat membantu untuk memecahkan berbagai persoalan penelitian kuantitatif. Dengan SPSS, kita dapat mengetahui nilai rata-rata, simpangan baku, skor terkecil, atau skor terbesar dari data yang kita miliki. Bahkan, kita dapat mengetahui frekuensi data kita, persentasenya, sampai menyajikan data kita ke dalam histogram atau diagram lingkaran. Dengan SPSS juga, kita dapat mencari validitas (kesahihan) dan reliabilitas (keandalan) instrumen penelitian kita, normalitas data, kuat atau besar hubungan antara dua variabel, mencari perbedaan rata-rata antara dua kelompok, ataupun melakukan analisis faktor. Secara rinci akan dijelaskan langkah-langkah penggunaan SPSS yang paling mendasar, seperti membuat variabel, menginput data kedalam SPSS, ataupun menghitung total skor.
\end{abstract}

\section{Kata Kunci : Konsep, Uji, Validitas, Reliabilitas, SPSS}

\section{A. PENDAHULUAN}

SPSS merupakan suatu singkatan dari Statistical Product and Service Solution. SPSS merupakan bagian integral dari rentang proses analisa, menyediakan akses data. SPSS dapat membaca berbagai jenis data atau memasukkan data secara langsung ke dalam SPSS Data Editor. Pengujian Validitas dapat dilakukan dengan menggunakan aplikasi SPSS. Uji Validitas merupakan uji yang digunakan untuk mengukur tingkat keefktifan suatu alat ukur atau media ukur untuk memperoleh data. Biasanya digunakan untuk mengukur seberapa efektif suatu kuesioner untuk memperoleh data, lebih tepat untuk pertanyaan-pertanyaan yang diajukan di kuesioner. Dalam statistik, selain menguji apakah data terdistribusi normal atau tidak, kita juga harus menguji apakah data dapat diandalkan dan tetap konsisten apabila pengukurannya dilakukan berulang kali. Berkaitan dengan menguji data yang dapat diandalkan dan konsisten, dapat dilakukan uji reliabilitas data. Selain uji normalitas data, uji reliabilitas data juga dapat dilakukan dengan menggunakan SPSS. Sehingga, memungkin untuk menguji data dalam jumlah yang banyak. Dan dalam artikel kali ini kita akan membahas tetang uji validitas dan reliabilitas dengan menggunakan SPSS. 


\section{B. PEMBAHASAN}

\section{Uji Validitas Menggunakan SPSS}

* Pengertian Uji Validitas

Sebagai awalan, sebelum melakukan uji validitas menggunakan SPSS. Mari kita mengenal uji validitas secara teorinya. Hal ini harus kita pahami bersama agar kita tahu apa maksudnya dilakukan uji validitas. Uji validitas merupakan uji yang berfungsi untuk melihat apakah suatu alat ukur tersebut valid (sahih) atau tidak valid. Alat ukur yang dimaksud disini merupakan pertanyaan-pertanyaan yang ada dalam kuesioner. Suatu kuesioner dikatakan valid jika pertanyaan tersebut pada kuesioner dapat mengungkapkan sesuatu yang diukur oleh kuesioner. Misalnya, kita ingin mengukur Kinerja Karyawan. Untuk melihat tingkat kinerja karyawan, karyawan tersebut diberi lima pertanyaan, maka lima pertanyaan tersebut harus tepat mengungkapkan bagaimana kinerja karyawan. Dalam uji pengukuran validitas terdapat dua macam yaitu Pertama, mengkorelasikan antar skor butir pertanyaan (item) dengan total item. Kedua, mengkorelasikan antar masing-masing skor indikator item dengan total skor konstruk.

\section{* Kriteria Pengujian Validitas}

Dalam artikel ini, akan menjelaskan pengujian validitas yang mengkorelasikan antar masing-masing skor item indikator dengan total skor konstruk. Tingkat signifikansi yang digunakan yaitu 0,05 .

$\checkmark$ Kriteria pengujiannya yaitu:

H0 diterima apabila $\mathrm{r}$ hitung $>\mathrm{r}$ tabel, (alat ukur yang digunakan valid atau sahih)

$\mathrm{H} 0$ ditolak apabila $r$ statistik $\leq r$ tabel. (alat ukur yang digunakan tidak valid atau sahih)

$\checkmark \quad$ Cara menentukan besar nilai R tabel

$\mathrm{R}$ tabel $=\mathrm{df}(\mathrm{N}-2)$, tingkat signifikansi uji dua arah.

Misalnya $\mathrm{R}$ tabel $=\mathrm{df}(13-2,0,05)$. Untuk mendapatkan nilai $\mathrm{R}$ tabel kita harus melihat ditebal R.

\section{* Langkah Melakukan Uji Validitas}

Nah, sekarang kita sudah masuk ke pembahasan ketiga yaitu pengujian menggunakan SPSS. Untuk praktek latihan menggunakan SPSS versi 22. Variabel yang akan di uji adalah variabel Sosialisasi (X1). Dikarenakan pengujian Validitas merupakan pengujian yang menguji masing-masing item pertanyaan variabel maka hanya akan mencontohkan satu variabel saja. Tenang saja, pengujian ini caranya sama untuk menguji variabel independent ataupun variabel dependent. Setelah itu, silahkan persiapkan data penelitiannya. Data yang ingin kita uji. Apabila kita belum ada data yang hendak diuji, untuk sementara kita bisa menggunakan contoh data dibawah yaa.

Adapun Langkah-langkah pengujiannya, yaitu sebagai berikut :

> Buka aplikasi SPSS. Silahkan atur format yang ada di Variable View. Sesuaikan dengan kriteria data kita. Contohnya seperti ini. 


\begin{tabular}{|c|c|c|c|c|c|c|c|c|c|c|c|}
\hline & Farme & Type & Whath & Dectmals & Label & Values & Wossung & Column & Alyp & Meanar & Rile \\
\hline 1 & $x+1$ & Nhumenc & B & 0 & & Wane & those & 1 & E Rigtt & 2. Nominal & Y lnout \\
\hline 2. & $x 12$ & Pavmenc & 8 & 0 & & Niane & Nowe & 0 & E Righe & a. Nominal & $\checkmark$ hout \\
\hline 3 & $x+3$ & thumesce & 8 & 0 & & Nane & those & 1 & E Regt & 2. Nominal & $\checkmark$ hont \\
\hline 4 & $x+4$ & Nownenic & 0 & 0 & & Hone. & Nover & 1 & a Rigle & D. Noninal & $\checkmark$ houl \\
\hline 5 & $\times 1.5$ & Nowmenc & 6 & 0 & & thone & thenes & 1 & a Right & d. tomnal & $\checkmark$ hout \\
\hline 6 & $x+6$ & Numenc & 8 & 0 & & Wane & thone & 1 & E Roght & 2. Nominal & $\checkmark$ mat \\
\hline 7 & xhoes & Damene. & 8 & 0 & & Nane & thene & 8 & E Rapht & 8 Scale & $\checkmark$ input \\
\hline \multicolumn{12}{|l|}{3} \\
\hline \multicolumn{12}{|l|}{3} \\
\hline \multirow[t]{2}{*}{$\pi$} & & & & & & & & & & & \\
\hline & $t$ & & & & & & & & & & \\
\hline ta West & Variatie View & & & & & & & & & & \\
\hline
\end{tabular}

Lalu, Input Data Kita di Data View.

\begin{tabular}{|c|r|r|r|r|r|r|r|r|}
\hline & X1.1 & X1.2 & X1.3 & X1.4 & X1.5 & X1.6 \\
\hline 1 & 4 & 4 & 4 & 4 & 4 & 3 \\
\hline \hline 2 & 5 & 5 & 5 & 5 & 5 & 4 \\
\hline \hline 3 & 4 & 4 & 4 & 4 & 4 & 3 \\
\hline \hline 4 & 4 & 4 & 4 & 5 & 4 & 4 \\
\hline \hline 5 & 4 & 3 & 4 & 4 & 4 & 4 \\
\hline \hline 6 & 4 & 4 & 4 & 5 & 5 & 5 \\
\hline \hline 7 & 5 & 5 & 5 & 5 & 5 & 5 \\
\hline \hline 8 & 4 & 4 & 4 & 4 & 4 & 4 \\
\hline \hline 9 & 4 & 4 & 5 & 4 & 4 & 5 \\
\hline \hline 10 & 4 & 5 & 5 & 4 & 4 & 5 \\
\hline \hline 11 & 4 & 4 & 4 & 4 & 4 & 4 \\
\hline \hline 12 & 4 & 5 & 4 & 4 & 5 & 4 \\
\hline \hline 13 & 4 & 4 & 4 & 4 & 4 \\
\hline \hline 14 & 4 & & 4 & & & & \\
\hline \hline
\end{tabular}

Selanjutnya, kita mencari nilai total dari variabel X. Caranya klik menu Transform> Compute Variable.

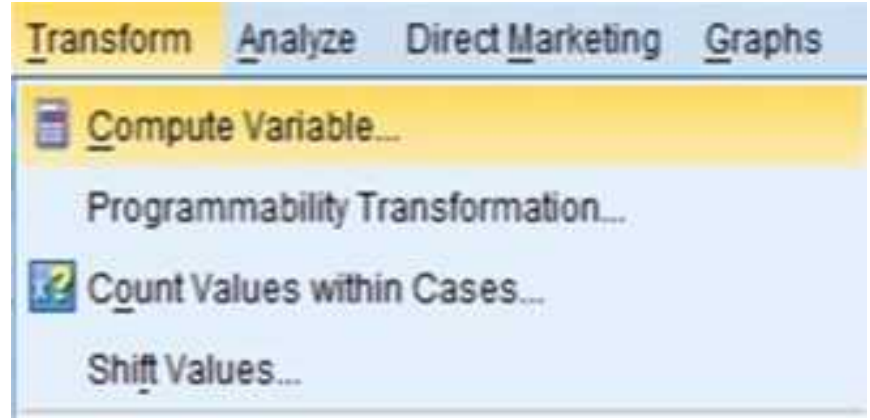

Maka akan muncul kotak dialog. Lalu, lakukan pengisian di kolom Target Variable dan Numeric Expression seperti gambar dibawah. Lalu, klik OK. 


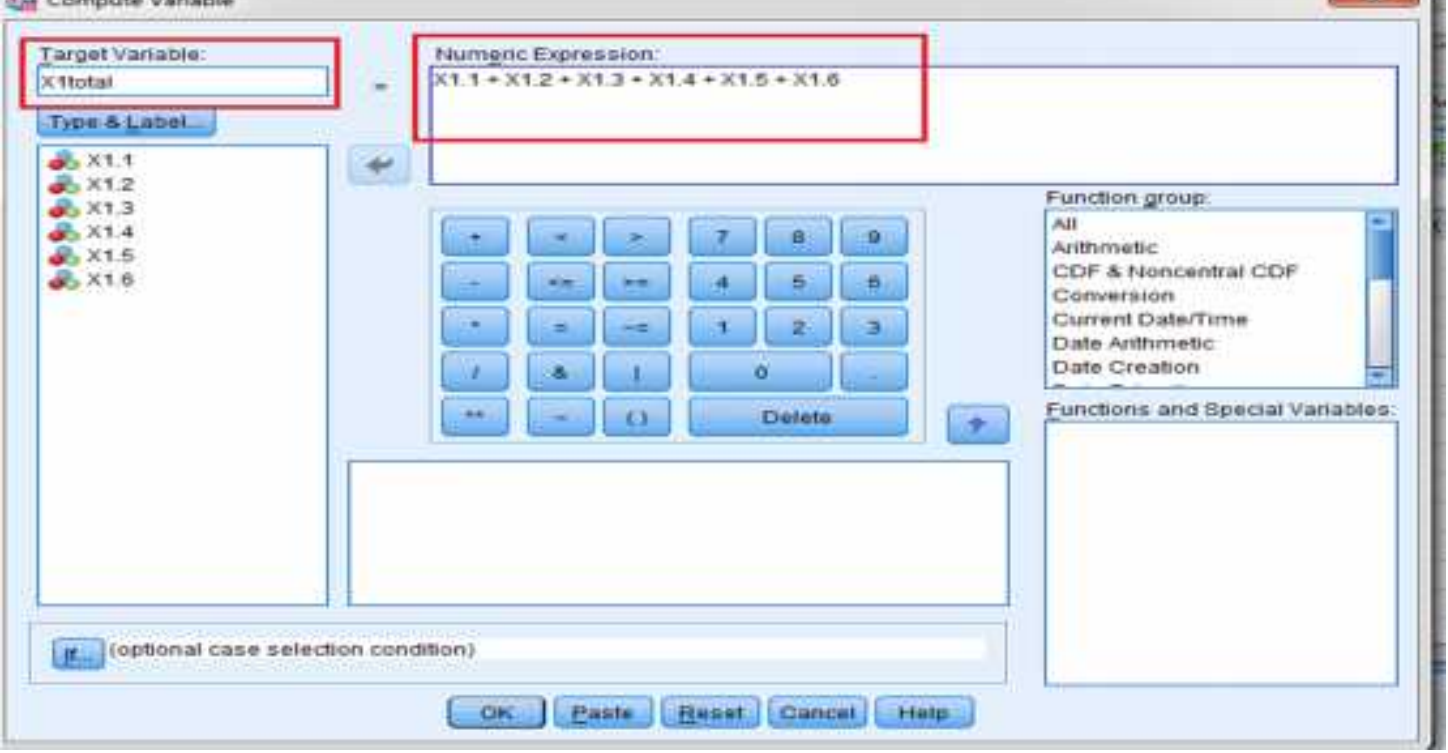

Lihatlah data pada 'Data View' akan ada penambahan kolom baru yaitu kolom X1total.

\begin{tabular}{|c|c|c|c|c|c|c|c|c|}
\hline & 1.1 & $\mathrm{X} 1.2$ & $\times 1.3$ & $\times 1.4$ & $\times 1.5$ & $X 1.6$ & X1total & $\checkmark$ \\
\hline & 4 & 4 & 4 & 4 & 4 & 3 & 23 & \\
\hline & 5 & 5 & 5 & 5 & 5 & 4 & 29 & \\
\hline & 4 & 4 & 4 & 4 & 4 & 3 & 23 & \\
\hline & 4 & 4 & 4 & 5 & 4 & 4 & 25 & \\
\hline & 4 & 3 & 4 & 4 & 4 & 4 & 23 & \\
\hline & 4 & 4 & 4 & 5 & 5 & 5 & 27 & \\
\hline & 5 & 5 & 5 & 5 & 5 & 5 & 30 & \\
\hline & 4 & 4 & 4 & 4 & 4 & 4 & 24 & \\
\hline & 4 & 4 & 5 & 4 & 4 & 5 & 26 & \\
\hline 1 & 4 & 5 & 5 & 4 & 4 & 5 & 27 & \\
\hline 1 & 4 & 4 & 4 & 4 & 4 & 4 & 24 & \\
\hline$t$ & 4 & 5 & 4 & 4 & 5 & 4 & 26 & \\
\hline 1 & 4 & 4 & 4 & 4 & 4 & 4 & 24 & \\
\hline f & & & & & & & & \\
\hline & $1+\mathrm{E}$ & & & & & & & \\
\hline
\end{tabular}

Selanjutnya, kita akan mencari nilai R statistik atau R hitung. Caranya klik Analyze> Correlate> Bivariate. Maka akan muncul kotak dialog.

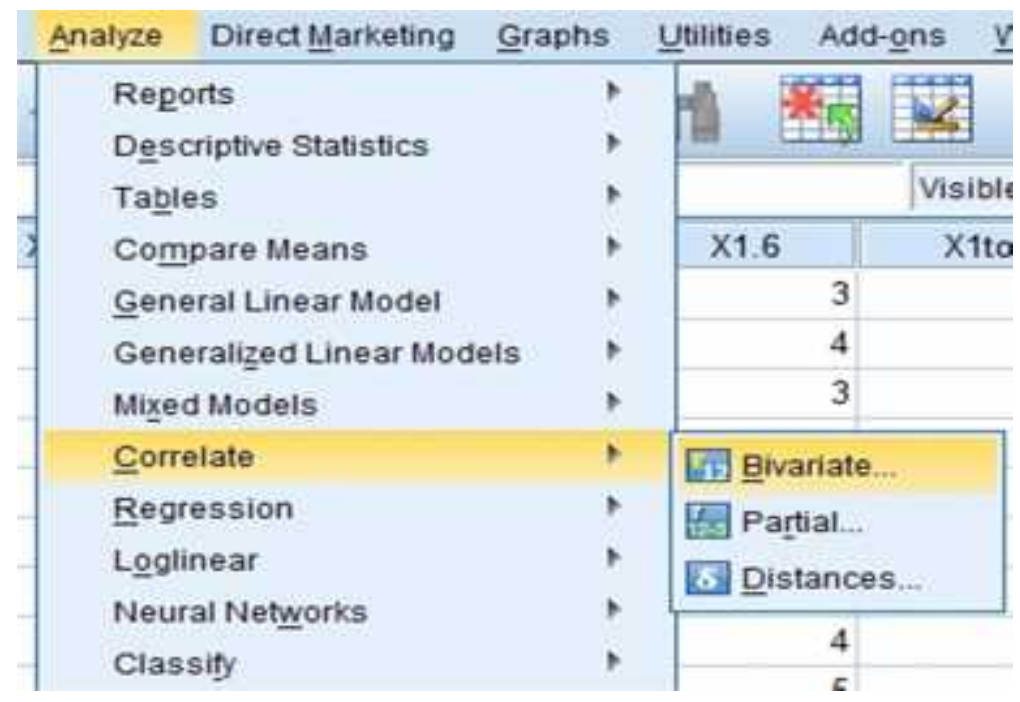


$>$ Lalu, pindahkan semua item variabel ke kotak Variables. Pada Correlation Coefficients beri centang pada Pearson. Dibawahnya centang Two-Tailed dan juga centang Flag Significant Correlation. Lalu, klik OK

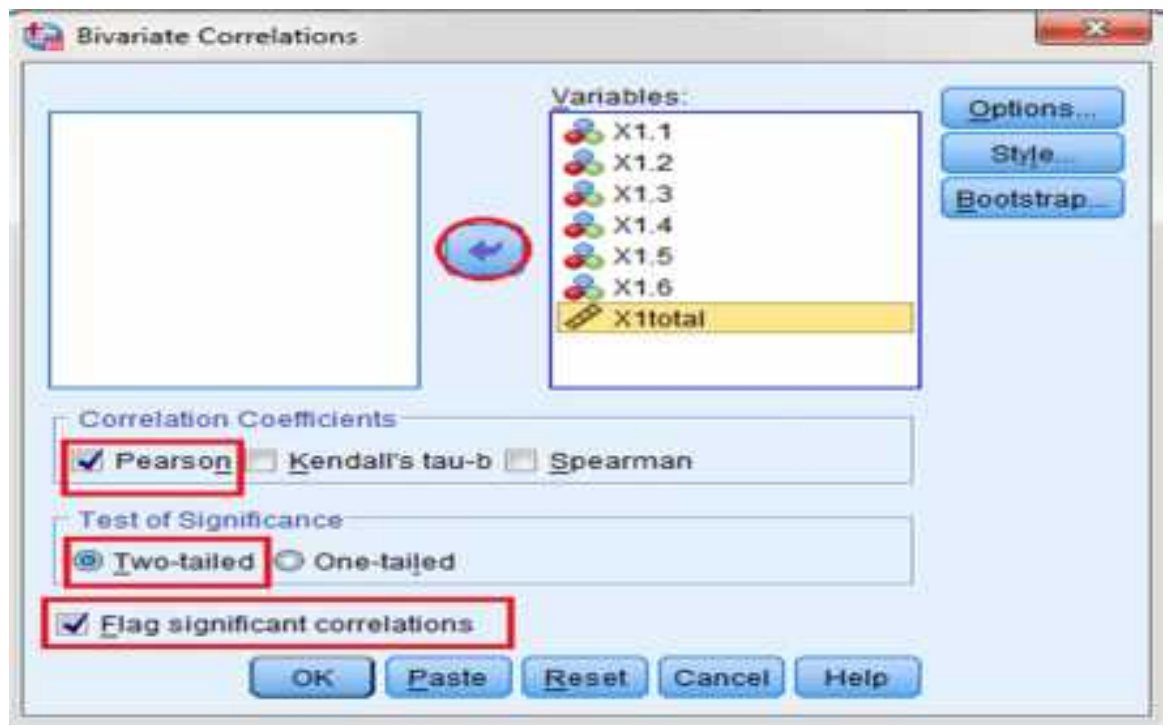

Maka akan muncul hasilnya. Perhatikan pada kolom 'Correlations'. Nilai yang akan kita uji adalah nilai pada kolom paling bawah bagian X1total yaitu 'Pearson Correlation'.

Correlations

\begin{tabular}{|c|c|c|c|c|c|c|c|}
\hline & X1.1 & $X 1.2$ & $\mathrm{X} 1.3$ & X1.4 & X1.5 & X1.6 & X1 total \\
\hline \multirow{3}{*}{$\begin{array}{l}\text { X1.1 Pearson } \\
\text { Correlation Sig. } \\
\text { (2-tauled) N }\end{array}$} & 1 & 570 & 640 & 640 & 640 & 223 & 781 \\
\hline & & 042 & 019 & 019 & 019 & 464 & 002 \\
\hline & 13 & 13 & 13 & 13 & 13 & 13 & 13 \\
\hline \multirow{3}{*}{$\begin{array}{l}\text { X1.2 Pearson } \\
\text { Correlation Sig. } \\
\text { (2-tauled) N }\end{array}$} & 570 & 1 & 601 & 312 & 601 & 311 & 764 \\
\hline & 042 & & 030 & 300 & 030 & 302 & 002 \\
\hline & 13 & 13 & 13 & 13 & 13 & 13 & 13 \\
\hline \multirow{3}{*}{$\begin{array}{l}\text { X1.3 Pearson } \\
\text { Correlation Sig. } \\
\text { (2-tauled) N }\end{array}$} & 640 & 601 & 1 & 278 & 278 & 601 & 767 \\
\hline & 019 & 030 & & 358 & 358 & 030 & 002 \\
\hline & 13 & 13 & 13 & 13 & 13 & 13 & 13 \\
\hline \multirow{3}{*}{$\begin{array}{l}\text { X1.4 Pearson } \\
\text { Correlation Sig. } \\
\text { (2-tauled) N }\end{array}$} & 640 & 312 & 278 & 1 & 639 & 349 & 692 \\
\hline & 019 & 300 & 358 & & 019 & 243 & 009 \\
\hline & 13 & 13 & 13 & 13 & 13 & 13 & 13 \\
\hline \multirow{3}{*}{$\begin{array}{l}\text { X1.5 Pearson } \\
\text { Correlation Sig. } \\
\text { (2-tauled) N }\end{array}$} & 640 & 601 & 278 & 639 & 1 & 349 & 767 \\
\hline & 019 & 030 & 358 & 019 & & 243 & 002 \\
\hline & 13 & 13 & 13 & 13 & 13 & 13 & 13 \\
\hline \multirow{3}{*}{$\begin{array}{l}\text { X1.6 Pearson } \\
\text { Correlation Sig. } \\
\text { (2-tauled) N }\end{array}$} & 223 & 311 & 601 & 349 & 349 & 1 & 689 \\
\hline & 464 & 302 & 030 & 243 & 243 & & 009 \\
\hline & 13 & 13 & 13 & 13 & 13 & 13 & 13 \\
\hline \multirow{3}{*}{$\begin{array}{l}\text { X1 total Pearson } \\
\text { Correlation Sig. } \\
\text { (2-tauled) N }\end{array}$} & 781 & 764 & 767 & 692 & 767 & 689 & 1 \\
\hline & 002 & 002 & 002 & 009 & 002 & 009 & \\
\hline & 13 & 13 & 13 & 13 & 13 & 13 & 13 \\
\hline
\end{tabular}


- Correlation is significant at the 0.05 level (2-tailed).

- Correlation is significant at the 0.01 level (2-tailed).

* Interpretasi Uji Validitas

Nah, selanjutnya kita akan menginterpretasikan atau menjelaskan hasil pengujian kita yang diatas. Dari sini kita akan melihat jawaban dari hasil pengujian kita yang baru. Yuk, kita mulai menginterpretasi.

Pertama, kita harus mencari nilai R tabel terlebih dahulu. Sesuai ketentuan dari df (N-2, 0,05). $\mathrm{N}$ adalah jumlah data yang diuji. Jadi, untuk mencari nilai $\mathrm{R}$ tabel kita menggunakan ketentuan: $\mathrm{R}$ tabel $=\mathrm{df}(13-2,0,05)=0,5529$

\begin{tabular}{|ccccccc|}
\hline & \multicolumn{5}{c|}{ Tingkat Signifikansi Untuk Uji Satu Arah } \\
\cline { 2 - 6 } $\mathbf{d f}=(\mathbf{N}-2)$ & 0.05 & 0.025 & 0.01 & 0.005 & 0.0005 \\
\cline { 2 - 6 } & \multicolumn{5}{c}{ Tingkat Signifikansi Untuk Uji Dua Arah } \\
\hline & 0.1 & 0.05 & 0.02 & 0.01 & 0.001 \\
\hline $\mathbf{1}$ & 0.9877 & 0.9969 & 0.9995 & 0.9999 & 1.0000 \\
\hline $\mathbf{2}$ & 0.9000 & 0.9500 & 0.9800 & 0.9900 & 0.9990 \\
\hline $\mathbf{3}$ & 0.8054 & 0.8783 & 0.9343 & 0.9587 & 0.9911 \\
\hline $\mathbf{4}$ & 0.7293 & 0.8114 & 0.8822 & 0.9172 & 0.9741 \\
\hline $\mathbf{5}$ & 0.6694 & 0.7545 & 0.8329 & 0.8745 & 0.9509 \\
\hline $\mathbf{6}$ & 0.6215 & 0.7067 & 0.7887 & 0.8343 & 0.9249 \\
\hline $\mathbf{7}$ & 0.5822 & 0.6664 & 0.7498 & 0.7977 & 0.8983 \\
\hline $\mathbf{8}$ & 0.5494 & 0.6319 & 0.7155 & 0.7646 & 0.8721 \\
\hline $\mathbf{9}$ & 0.5214 & 0.6021 & 0.6851 & 0.7348 & 0.8470 \\
\hline $\mathbf{1 0}$ & 0.4973 & 0.5760 & 0.6581 & 0.7079 & 0.8233 \\
\hline $\mathbf{1 1}$ & 0.4762 & 0.5529 & 0.6339 & 0.6835 & 0.8010 \\
\hline $\mathbf{1 2}$ & 0.4575 & 0.5324 & 0.6120 & 0.6614 & 0.7800 \\
\hline $\mathbf{1 3}$ & 0.4409 & 0.5140 & 0.5923 & 0.6411 & 0.7604 \\
\hline $\mathbf{1 4}$ & 0.4259 & 0.4973 & 0.5742 & 0.6226 & 0.7419 \\
\hline $\mathbf{1 5}$ & 0.4124 & 0.4821 & 0.5577 & 0.6055 & 0.7247 \\
\hline $\mathbf{1 6}$ & 0.4000 & 0.4683 & 0.5425 & 0.5897 & 0.7084 \\
\hline $\mathbf{1 7}$ & 0.3887 & 0.4555 & 0.5285 & 0.5751 & 0.6932 \\
\hline
\end{tabular}

Kedua, bandingkan nilai $\mathrm{R}$ tabel dan $\mathrm{R}$ hitung sesuai kriteria pengujian.

$\mathrm{X} 1.1=0,781>0,552$, maka H0 diterima artinya alat ukur yang digunakan valid atau sahih.

$\mathrm{X} 1 \cdot 2=0,764>0,552$, maka H0 diterima artinya alat ukur yang digunakan valid atau sahih.

Dan seterusnya...

$>$ Ketiga, cara lain selain menggunakan $\mathrm{R}$ hitung yaitu melihat tingkat signifikansinya. Apabila tingkat signifikansi item $<0,05$ maka alat ukur yang digunakan valid.

\section{Uji Reliabilitas Data dengan Menggunakan SPSS}

* Pengertian Uji Reliabilitas Data

Menurut Notoatmodjo (2005) dalam Widi R (2011), reliabilitas adalah indeks yang menunjukkan sejauh mana suatu alat pengukur dapat dipercaya atau diandalkan. Sehingga uji reliabilitas dapat digunakan untuk mengetahui konsistensi alat ukur, apakah alat ukur tetap 
konsisten jika pengukuran tersebut diulang. Alat ukur dikatakan reliabel jika menghasilkan hasil yang sama meskipun dilakukan pengukuran berkali-kali.

Biasanya sebelum dilakukan uji reliabilitas data, dilakukan uji validitas data. Hal ini dikarenakan data yang akan diukur harus valid, dan baru dilanjutkan dengan uji reliabilitas data. Namun, apabila data yang diukur tidak valid, maka tidak perlu dilakukan uji reliabilitas data.

\section{* Jenis Uji Reliabilitas Data}

Terdapat beberapa metode yang dapat dilakukan untuk menguji reliabilitas data, yaitu sebagai berikut :

$\checkmark$ Tes Ulang

$\checkmark$ Formula Flanagan

$\checkmark$ Cronbach's Alpha

$\checkmark$ Formula KR (Kuder-Richardson)

$\checkmark$ Anova Hoyt

Walaupun terdapat beberapa metode uji reliabilitas, namun biasanya untuk data penelitian dan kuesioner digunakan metode Cronbach's Alpha. Pada artikel ini akan dijelaskan bagaimana cara melakukan uji reliabilitas dengan metode Cronbach's Alpha menggunakan SPSS.

\section{* Uji Reliabilitas Metode Cronbach's Alpha}

Menurut Suharsimi Arikunto (2010), Cronbach's Alpha digunakan untuk mencari reliabilitas instrumen yang skornya bukan 1 atau 0. Pada metode Crobach's Alpha digunakan rumus sebagai berikut :

$$
\mathrm{r}_{11}=\left[\frac{k}{(k-1)}\right]\left\lceil 1-\frac{\Sigma \sigma_{b}^{2}}{\sigma_{t}^{2}}\right\rceil
$$

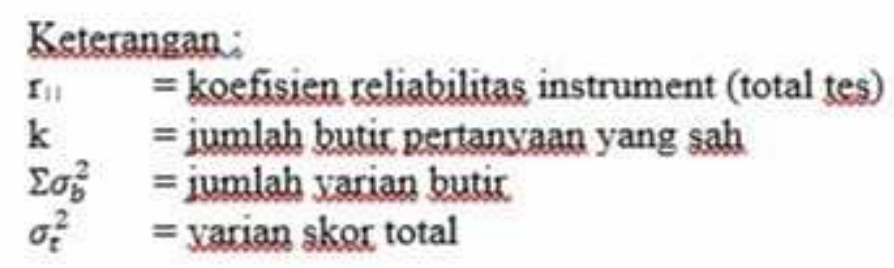

Perhitungan menggunakan rumus Cronbach's Alpha diterima, apabila perhitungan $\mathrm{r}$ hitung > r tabel $5 \%$.

\section{* Cara Uji Reliabilitas Metode Cronbach's Alpha}

Berikut ini adalah cara perhitungan uji reliabilitas data metode Cronbach's Alpha dengan menggunakan SPSS yaitu sebagai berikut :

$>$ Pastikan kita sudah menginstall program SPSS, kemudian buka program SPSS

$>$ Siapkan data-data yang diperlukan (contoh: data kuesioner), kemudian entry data kuesioner ke dalam variable view dan data view.

Berikut ini adalah contoh data kuesioner dan responded yang akan digunakan pada artikel ini: 


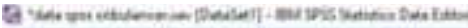

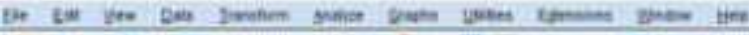

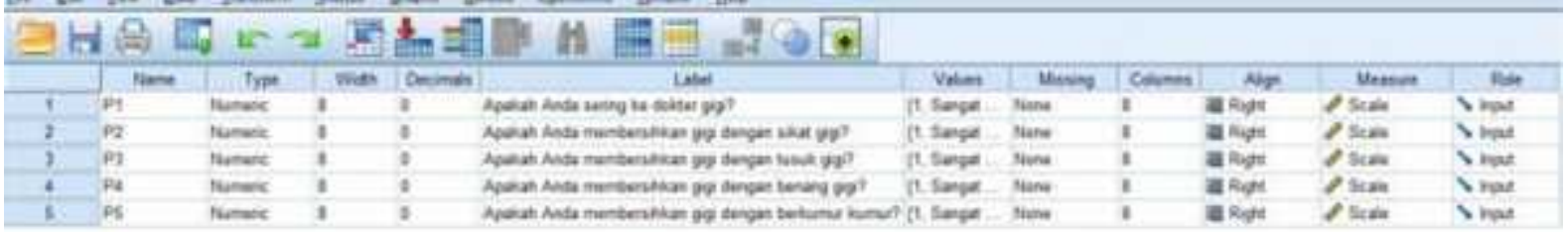

2.data spss sribulancer.sav [DataSet1] - IBM SPSS Statistics Data Editor

Eile Edit View Data Iransform Analyze Graphs Untilities Extension

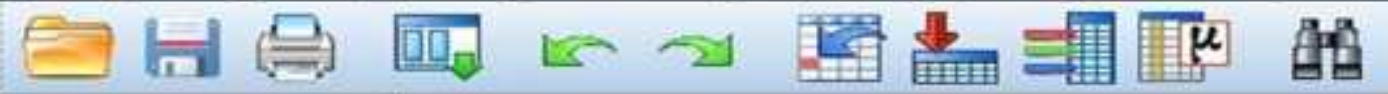

10: P5

2

\begin{tabular}{|c|c|c|c|c|c|}
\hline & \& P1 & $\& P 2$ & \& P3 & \& P4 & \& P5 \\
\hline 1 & 2 & 1 & 2 & 4 & 2 \\
\hline 2 & 2 & 1 & 2 & 4 & 2 \\
\hline 3 & 4 & 1 & 2 & 4 & 2 \\
\hline 4 & 4 & 1 & 5 & 5 & 2 \\
\hline 5 & 4 & 1 & 5 & 5 & 2 \\
\hline 6 & 1 & 1 & 4 & 5 & 2 \\
\hline 7 & 2 & 2 & 4 & 5 & 2 \\
\hline 8 & 1 & 1 & 2 & 2 & 2 \\
\hline 9 & 2 & 1 & 2 & 2 & 2 \\
\hline 10 & 1 & 1 & 2 & 2 & 2 \\
\hline
\end{tabular}

Kemudian, klik Analyze > Scale > Reliability Analysis...

QA *data spss sribulancer.aav [DataSet1] - IEM SPSS Statistics Data Editor

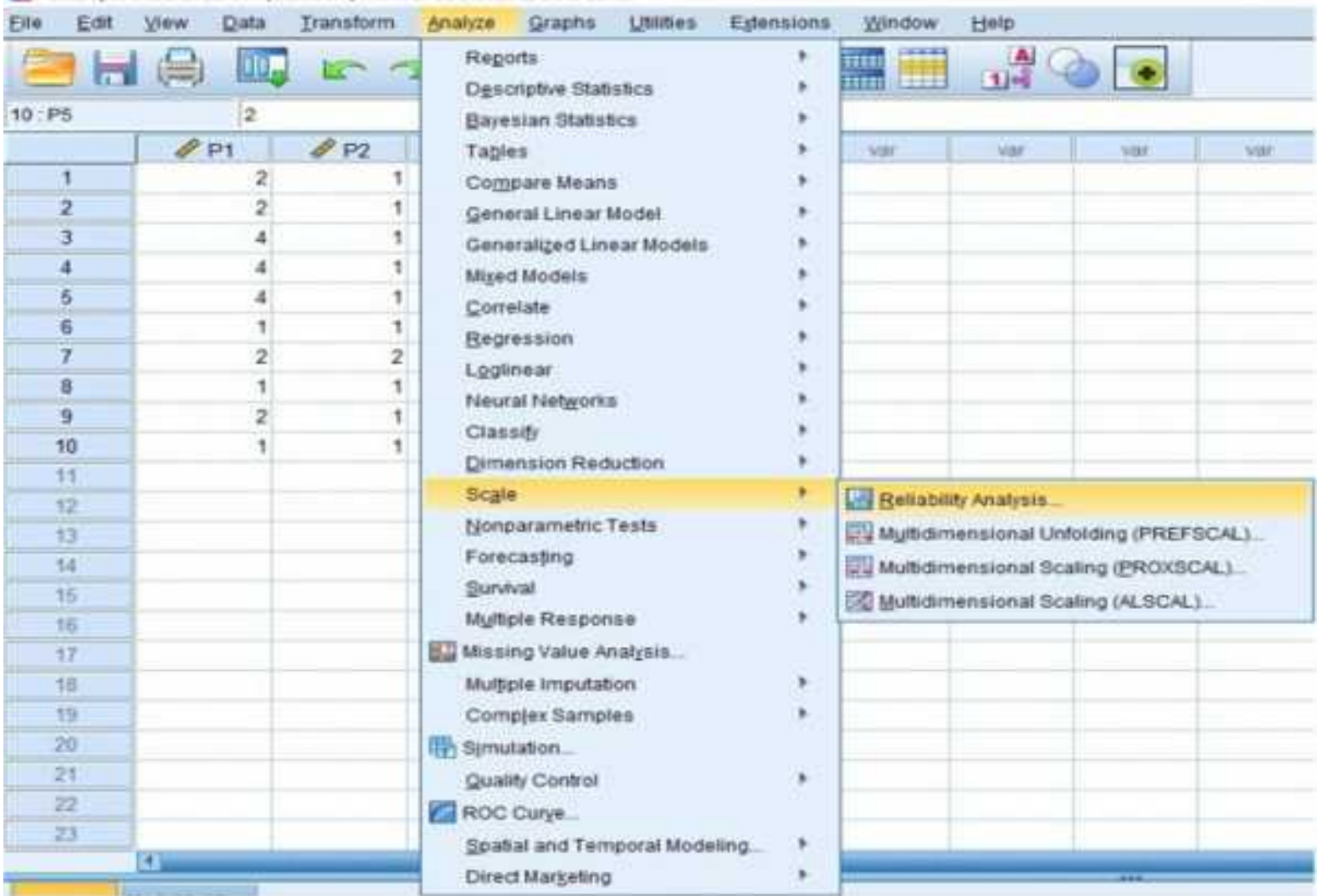


D Lalu, akan muncul tampilan Reliability Analysis. Pindahkan seluruh data variabel berupa skala ke kolom Items (ke sebelah kanan) dan pilih model Alpha.

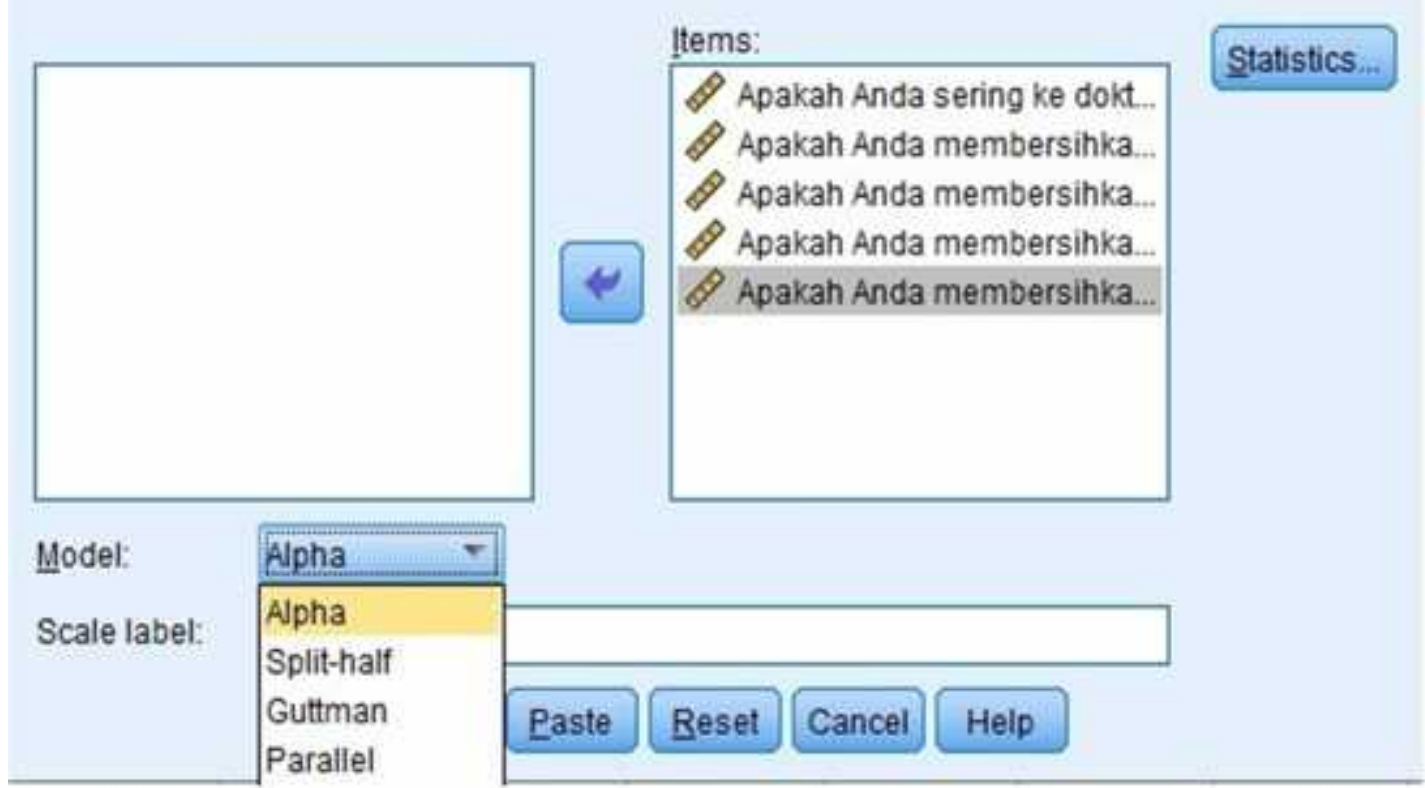

Setelah itu, klik Statistics..., akan muncul tampilan Reliability Analysis: Statistics, kemudian pada bagian Descriptive For centang Scale dan Scale if item deleted. Lalu klik Continue.

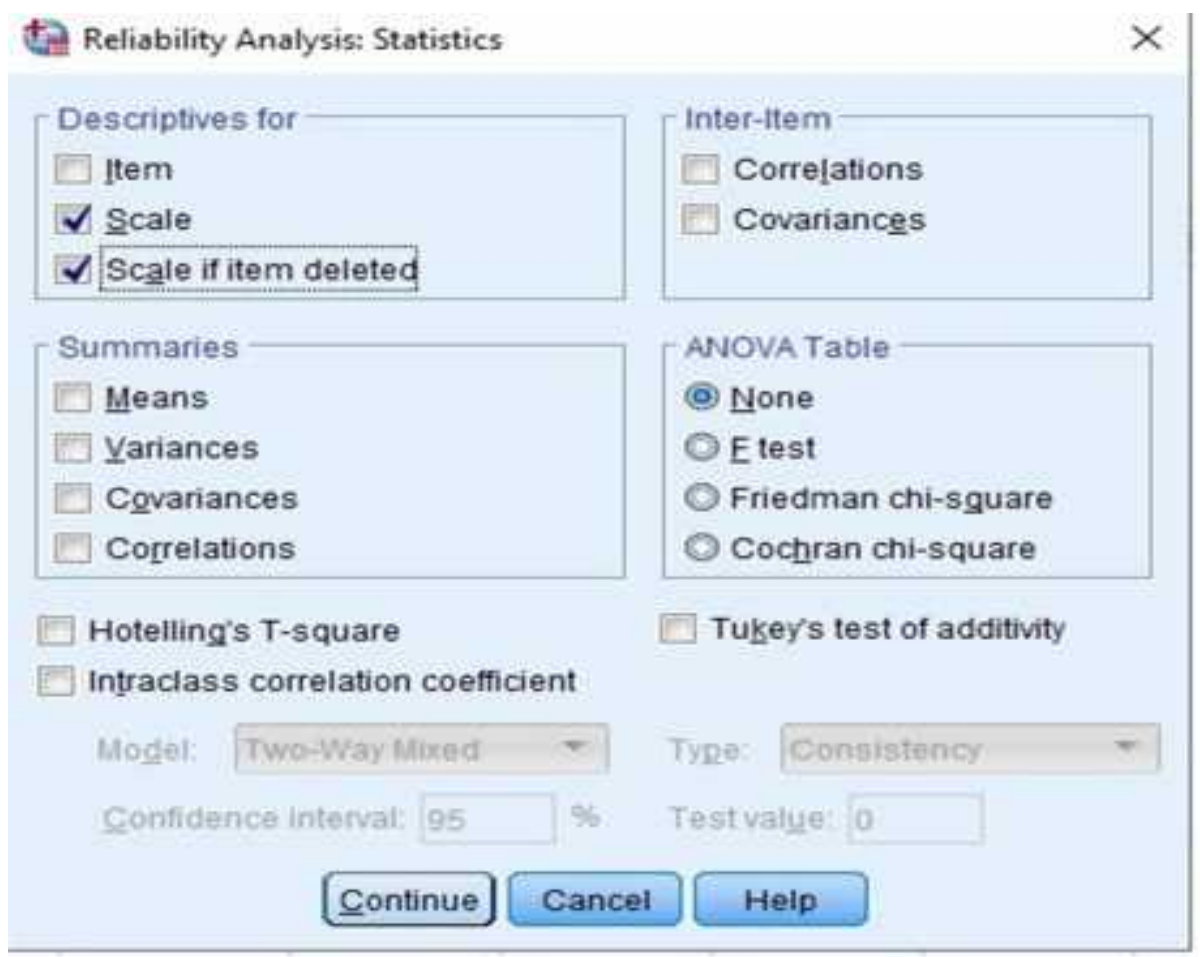

Kemudian, klik OK dan lihat hasil perhitungan data pada Output. 
Interpretasi Hasil Uji Reliabilitas Metode Cronbach's Alpha

Setelah melakukan perhitungan data, kemudian hasil perhitungan dengan uji reliabilitas akan muncul pada Output. Pada Output hasil perhitungan data akan berupa tabel, yaitu Case Processing Summary, Reliability Statistics, Item-Total Statistics, dan Scale Statistics.

\begin{tabular}{|c|c|c|c|}
\hline \multicolumn{2}{|c|}{ Case Processing Summary } & $\mathrm{N}$ & $\%$ \\
\hline \multirow{3}{*}{ Cases } & Valid & 10 & 100.0 \\
\cline { 2 - 4 } & Excluded & 0 & .0 \\
\cline { 2 - 4 } & Total & 10 & 100.0 \\
\hline
\end{tabular}

- Listwise deletion based on all variables in the procedure

Pada tabel Case Processing Summary dapat dilihat baris Cases Valid menyatakan bahwa jumlah responden ada 10 dan persentase menunjukkan $100 \%$, hal ini menandakan bahwa 10 responden tersebut valid dan tidak ada responden yang masuk ke kategori Exculded. Lalu, untuk mengetahui apakah hasil perhitungan data dapat dipercaya dan konsisten atau reliabel, dapat diperhatikan pada tabel Reliability Statistics. Seperti tabel dibawah ini.

\begin{tabular}{|cc|}
\hline \multicolumn{2}{|c|}{ Reliability Statistics } \\
\hline Cronbach's Alpha & N of Items \\
\hline $\mathbf{0 . 6 8 8}$ & $\mathbf{5}$ \\
\hline
\end{tabular}

Hasil perhitungan uji reliabilitas metode Cronbach's Alpha ( $\mathrm{r}$ hitung) dapat dilihat pada kolom Cronbach's Alpha, yaitu 0.688 dengan $\mathrm{N}$ of Items menunjukkan bahwa jumlah dari items atau jumlah pertanyaan yang kamu input pada variable view adalah 5. Sehingga dapat dikatakan bahwa hasil Cronbach's Alpha untuk 5 data dari items atau 5 pertanyaan, yaitu 0.688 .

Kemudian, untuk mengetahui apakah data tersebut dapat dipercaya atau tidak, maka apabila perhitungan $\mathrm{r}$ hitung $>\mathrm{r}$ tabel 5\%, dimana $\mathrm{r}$ hitung dilihat dari tabel hasil perhitungan yang kamu dapatkan pada SPSS, sedangkan $r$ tabel 5\% dilihat pada tabel yang telah ditentukan, seperti dibawah ini:

DISTRIBUSI NILAI $r$ tabel SIGNIFIKANSI 5\% dan $1 \%$

\begin{tabular}{|c|c|ccccc|}
\hline \multirow{2}{*}{$\mathbf{N}$} & \multicolumn{2}{c}{ The Level Of Significance } & & \multicolumn{2}{c|}{ The Level Of Significance } \\
\cline { 2 - 3 } & $\mathbf{5} \%$ & $1 \%$ & & $5 \%$ & $1 \%$ \\
\hline $\mathbf{3}$ & 0.997 & 0.999 & 38 & 0.320 & 0.413 \\
\hline $\mathbf{4}$ & 0.950 & 0.990 & 39 & 0.316 & 0.408 \\
\hline $\mathbf{5}$ & 0.878 & 0.959 & 40 & 0.312 & 0.403 \\
\hline $\mathbf{6}$ & 0.811 & 0.917 & 41 & 0.308 & 0.398 \\
\hline $\mathbf{7}$ & 0.754 & 0.874 & 42 & 0.304 & 0.393 \\
\hline $\mathbf{8}$ & 0.707 & 0.834 & 43 & 0.301 & 0.389 \\
\hline $\mathbf{9}$ & 0.666 & 0.798 & 44 & 0.297 & 0.384 \\
\hline $\mathbf{1 0}$ & 0.632 & 0.765 & 45 & 0.294 & 0.380 \\
\hline $\mathbf{1 1}$ & 0.602 & 0.735 & 46 & 0.291 & 0.376 \\
\hline $\mathbf{1 2}$ & 0.576 & 0.708 & 47 & 0.288 & 0.372 \\
\hline
\end{tabular}




\begin{tabular}{|c|c|c|c|c|c|}
\hline 13 & 0.553 & 0.684 & 48 & 0.284 & 0.368 \\
\hline 14 & 0.532 & 0.661 & 49 & 0.281 & 0.364 \\
\hline 15 & 0.514 & 0.641 & 50 & 0.279 & 0.361 \\
\hline 16 & 0.497 & 0.623 & 55 & 0.266 & 0.345 \\
\hline 17 & 0.482 & 0.606 & 60 & 0.254 & 0.330 \\
\hline 18 & 0.468 & 0.590 & 65 & 0.244 & 0.317 \\
\hline 19 & 0.456 & 0.575 & 70 & 0.235 & 0.306 \\
\hline 20 & 0.444 & 0.561 & 75 & 0.227 & 0.296 \\
\hline 21 & 0.433 & 0.549 & 80 & 0.220 & 0.286 \\
\hline 22 & 0.432 & 0.537 & 85 & 0.213 & 0.278 \\
\hline 23 & 0.413 & 0.526 & 90 & 0.207 & 0.267 \\
\hline 24 & 0.404 & 0.515 & 95 & 0.202 & 0.263 \\
\hline 25 & 0.396 & 0.505 & 100 & 0.195 & 0.256 \\
\hline 26 & 0.388 & 0.496 & 125 & 0.176 & 0.230 \\
\hline 27 & 0.381 & 0.487 & 150 & 0.159 & 0.210 \\
\hline 28 & 0.374 & 0.478 & 175 & 0.148 & 0.194 \\
\hline 29 & 0.367 & 0.470 & 200 & 0.138 & 0.181 \\
\hline 30 & 0.361 & 0.463 & 300 & 0.113 & 0.148 \\
\hline 31 & 0.355 & 0.456 & 400 & 0.098 & 0.128 \\
\hline 32 & 0.349 & 0.449 & 500 & 0.088 & 0.115 \\
\hline 33 & 0.344 & 0.442 & 600 & 0.080 & 0.105 \\
\hline 34 & 0.339 & 0.436 & 700 & 0.074 & 0.097 \\
\hline 35 & 0.334 & 0.430 & 800 & 0.070 & 0.091 \\
\hline 36 & 0.329 & 0.424 & 900 & 0.065 & 0.086 \\
\hline 37 & 0.325 & 0.418 & 1000 & 0.062 & 0.081 \\
\hline
\end{tabular}

Setelah itu, lihat nilai $\mathrm{N}$ sesuai dengan jumlah responden dari data kamu, pada contoh jumlah responden atau nilai $\mathrm{N}$, yaitu 10. Lihat pada $\mathrm{r}$ tabel 5\%, maka diketahui bahwa $\mathrm{r}$ tabel untuk data tersebut adalah 0.632. Lalu, dapat disimpulkan, bahwa $r$ hitung $>\mathrm{r}$ tabel $5 \%$, yaitu $0.688>0.632$, sehingga data tersebut adalah reliabel atau dapat dipercaya dan konsisten.

\section{PENUTUP}

SPSS adalah satu program untuk pengolahan data statistic yang penggunaannya cukup mudah. SPSS merupakan suatu singkatan dari Statistical Product and Service Solution. Dalam pengujian validitas dan reliabilitas dengan menggunakan program SPSS dapat dilakukan dengan menggunakan teknik Bivariate Pearson dan Corrected Item-Total Correlation. Dalam sebuah evaluasi alat yang digunakan digolongkan menjadi dua macam yaitu tes dan nontes. Teknik-teknik Evaluasi adalah suatu percobaan yang diadakan untuk mengetahui ada tidaknya hasil-hasil pelajaran tertentu pada seseorang murid atau kelompok murid. Tes itu sendiri mempunyai dua bentuk yaitu bentuk obyektif dan bentuk subyektif. Sebuah tes dikatakan baik sebagai alat pengukur harus memenuhi persyaratan tes yaitu diantaranya adalah tes itu harus mempunyai tingkat validitas dan reliabilitas yang tinggi. Selain validitas, sebuah tes dikatakan baik, juga mempunyai reliabilitas yang tinggi. Dalam pengujian validitas dan reliabilitas dapat menggunakan program SPSS. 


\section{DAFTAR PUSTAKA}

Kurniawan, Albert. 2009. Belajar Mudah SPSS Untuk Pemula Untuk Mahasiswa Dan Umum Disertai Latihan Soal Dan Kunci Jawaban. Yogyakarta: MediaKom

Arsyam, M. (2020). MANAJEMEN PENDIDIKAN ISLAM.

Ghozali, imam. (2016). Aplikasi Analisis Multivariete Dengan Program IBM SPSS 23 . Edisi 8. Semarang: Badan Penerbit-UNDIP

Herianto, H. (2020). Teknik Menulis Artikel Konseptual.

Sunarti, dan Selly Rahmawati. 2014 Penilaian dalam kurikulum 2013 membantu guru dan calon guru mengetahui langkah-langkah penilaian pembelajaran Yogyakarta: CV Andi Offiset.

HERIANTO, H. (2020). Telaah Kurikulum 2013: Hasil Revisi Tahun 2018

Ghozali, Imam. (2018). Aplikasi Analisis Multivariate Dengan Program IBM SPSS 25. Semarang : Badan Penerbit-UNDIP

Jusmiana, A., \& HERIANTO, H. (2020). Suplemen Materi Statistik Terapan dalam Ilmu Kesehatan.

Widi R. Uji validitas dan reliabilitas dalam penelitian epidemiologi kedokteran gigi. J.K.G Unej. 2011; 8 (1): 27-34.

Sapada, A. O., \& Arsyam, M. (2020). Ilmu Pengetahuan dan Teknologi Menurut Pandangan Islam.

Dewi DAAN. Modul III: Uji Validitas dan Reliabilitas. Statistika Terapan. Universitas Dipenogoro. 2018: 1-14.

Indah Sari. 2016. SPSS (Statistical Product and Service Solution). Dikutip dari https://www.slideshare.net.

Junaidi. 2010. https://junaidichaniago.wordpress.com/2010/05/24/download-tabel-r-lengkap/ 